https://doi.org/10.30758/0555-2648-2020-66-3-267-278

УДК 551.465

ОРИГИНАЛЬНАЯ СТАТЬЯ

ORIGINAL ARTICLE

\title{
DISTRIBUTION OF SUSPENDED PARTICULATE MATTER IN THE BARENTS SEA IN LATE WINTER 2019
}

\author{
STEFAN BUETTNER ${ }^{\prime *}$, VLADIMIR V. IVANOV V', HEIDEMARIE KASSENS ${ }^{4}$, \\ NIKITA A. KUSSE-TIUZ2 \\ AND THE SHIPBOARD SCIENCE TEAM
}

${ }^{1}$ - Institute for Ecosystem Research, Kiel University, Germany

2 - State Scientific Center of the Russian Federation Arctic and Antarctic Research Institute, St. Petersburg, Russia

3 - Lomonosov Moscow State University, Moscow, Russia

${ }^{4}$ - GEOMAR Helmholtz Centre for Ocean Research Kiel, Kiel, Germany

*sbuettner@ecology.uni-kiel.de

\begin{abstract}
Summary
Arctic summer and winter sea-ice extent is continuously declining as a result of climate change, affecting the hydrography and biogeochemical cycles on the seasonally ice-free Eurasian Shelves. The prolongation of the open-water season causes higher sediment resuspension and coastal erosion due to larger wind fetch and wave heights. This impacts the optical properties of the water column and hence biological productivity in this region. During "Transarktika-2019" leg 1 in late winter 2019, a comprehensive dataset of filtered water samples and optical data was collected throughout the central and northern Barents Sea. Combining suspended particulate matter concentrations obtained from water samples and optical data revealed a pronounced bottom nepheloid layer on the Barents Sea shelf even under ice-covered conditions. Moreover, the data indicate that the Franz Viktoria Trough could be a major pathway for sediment transport into the Eurasian Basin. Therefore, to link changes in sediment distribution and its impact on the ecosystem under a warming climate, further studies of sediment dynamics are required, particularly during winter.
\end{abstract}

Keywords: Barents Sea, oceanography, sedimentology.

For Citation: Buettner S., Ivanov V.V., Kassens H., Kusse-Tiuz N.A. and the shipboard Science Team. Distribution of suspended particulate matter in the Barents Sea in late winter 2019. Problemy Arktiki i Antarktiki. Arctic and Antarctic Research. 2020, 66 (3): 267 — 278. https://doi.org/10.30758/0555-2648-2020-66-3-267-278.

Received 21.07.2020

Revised 4.09.2020

Accepted 7.09.2020

\section{РАСПРЕДЕЛЕНИЕ ВЗВЕШЕННЫХ ЧАСТИЦ В БАРЕНЦЕВОМ МОРЕ В КОНЦЕ ЗИМЫ 2019 г.}

\author{
Ш. БЮТТНЕР ${ }^{*}$, В.В. ИВАНОВ ${ }^{2,3}$, Х. КАССЕНС, H.А. КУССЕ-ТЮЗ ${ }^{2}$ \\ И СУДОВАЯ НАУЧНАЯ ГРУППА
}


I - Институт по исследованию экосистем, университет Киля, Германия

2 - ГНЦ РФ Арктический и антарктический научно-исследовательский институт, Санкт-Петербург, Россия

3 - Московский государственный университет им. М.В. Ломоносова, Москва, Россия

4 - Центр морских исследований в объединении им. Гельмгольияа ГЕОМАР, Киль, Германия

*sbuettner@ecology.uni-kiel.de

\section{Резюме}

Летняя и зимняя площадь ледяного покрова в Арктике постоянно сокращается в результате изменения климата, воздействуя на гидрофизические и биогеохимические циклы на сезонно-безледных шельфах Евразийского бассейна. Возрастание продолжительности периода открытой воды приводит к увеличению образования взвешенного осадка и береговой эрозии в связи с увеличением ветровой нагрузки и высоты волн. Это влияет на оптические свойства водной толщи и, следовательно, на биологическую продуктивность в этом регионе. Во время первого этапа экспедиции «Трансарктика-2019» в конце зимы 2019 г. в центральной и северной частях Баренцева моря был собран обширный объем данных взвешенных частиц из фильтрованной воды и оптических данных. Совместный анализ данных о концентрации взвешенного вещества, полученных из проб воды, и оптических данных показал наличие ярко выраженного донного нефелоидного слоя на шельфе Баренцева моря даже в условиях наличия ледяного покрова. Более того, полученные результаты свидетельствуют о том, что желоб Франц-Виктория может быть основным путем переноса осадочного материала в Евразийский бассейн. Поэтому для того, чтобы связать изменения в распределении осадочных отложений и их влияние на экосистему в условиях потепления климата, необходимы дальнейшие исследования динамики осадочных отложений, особенно в зимний период.

Ключевые слова: Баренцево море, океанография, седиментология.

Для цитирования: Buettner S., Ivanov V.V., Kassens H., Kusse-Tiuz N.A. and the shipboard Science Team. Distribution of suspended particulate matter in the Barents Sea in late Winter 2019 // Проблемы Арктики и Антарктики. 2020. Т. 66. № 3. С. 267 - 278. https://doi.org/10.30758/0555-2648-2020-66-3-267-278.

Поступила 21.07.2020

После переработки 4.09.2020

Принята 7.09.2020

\section{INTRODUCTION}

The summer and winter sea-ice extent in the northern Barents Sea has been declining over recent years $[1,2]$. As a result, the open water period prolongs and is expected to lead to higher sediment resuspension, particularly in the shallow parts of the shelf sea, and to increased costal erosion due to larger wind fetch and wave heights [3, 4]. The suspended particulate matter (SPM) within the water column plays a critical role for the ecosystem by contributing to the amount of nutrient supply (e.g. [5, 6]) and by influencing the amount of sunlight penetrating through the water column, through absorption and scattering [7]. In order to assess possible impacts on the ecosystem by future changes in SPM distribution and its dynamics, it is necessary to fully evaluate and describe presentday sedimentological conditions.

Thus far, SPM investigations on the Siberian Arctic shelves were carried out in late summer / early autumn when sea ice and weather conditions are most favorable (e.g. [8]). In the surface water of the Barents Sea, SPM concentrations are mainly driven by the varying intensity of biological productivity reaching maximum values during spring bloom $[8,9]$. In the eastern Barents Sea, a pronounced layer of high SPM concentrations extends from the Kara Sea towards the northern Barents Sea 


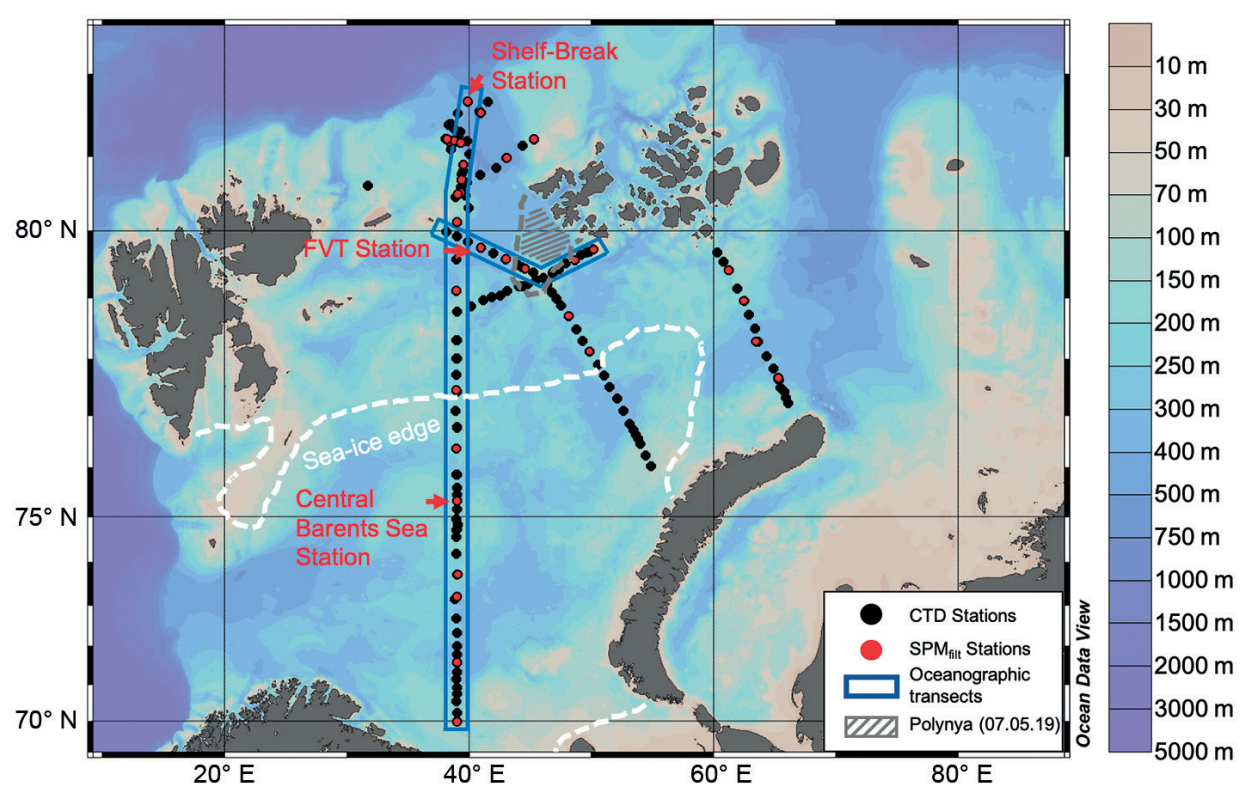

Fig. 1. Bathymetric map of the Barents Sea shelf(IBCAO V3.0 [17]) and the locations of oceanographic stations during "Transarktika-2019" leg 1 (black circles). Red circles indicate sampling stations for water samples. Blue boxes highlight the presented SPM transects. Grey area shows approximate location of a polynya on May 7th, 2019. White dashed line represents the ice edge at the beginning of the expedition on March 21, 2019

Рис. 1. Батиметрическая карта шельфа Баренцева моря (IBCAO V3.0 [17]) и расположение океанографических станций на первом этапе экспедиции «Трансарктика-2019» (черные кружки). Красными кружками отмечены станции с отбором проб на взвешенное вещество. Синим отмечены разрезы взвешенного вещества. Серым цветом показано приблизительное расположение полыньи 7 мая 2019 г. Белой пунктирной линией обозначена кромка льда в начале экспедиции 21 марта 2019 г.

shelf break in summertime [10]. This bottom nepheloid layer is sustained by sediment input of rivers, $\mathrm{Ob}$ and Yenisei, in the south and by cascading dense shelf water carrying resuspended material [9]. However, in the Franz Viktoria Trough region only low SPM concentrations are observed in the water column during early autumn [8]. Similar investigations on the central and eastern Laptev Sea shelf also showed two pronounced layers of high SPM concentrations at the surface and at the bottom during summer. There, its occurrence and extent are mainly linked to prevailing atmospheric conditions and the turbid outflow of the Lena river [11, 12]. The presence of bottom nepheloid layers (BNL) are crucial for benthic organisms as they feed on the suspended material [13]. Furthermore, most of the cross-shelf sediment transport [11] as well as export of organic carbon off the shelf takes place within the BNL [14, 15]. In order to assess the distribution of suspended particles in a year-round perspective reliable in situ data during wintertime is needed. In this study we present combined results from SPM measurements and optical backscatter data obtained during "Transarktika-2019" leg 1 [16], in late winter 2019 (Fig. 1). 


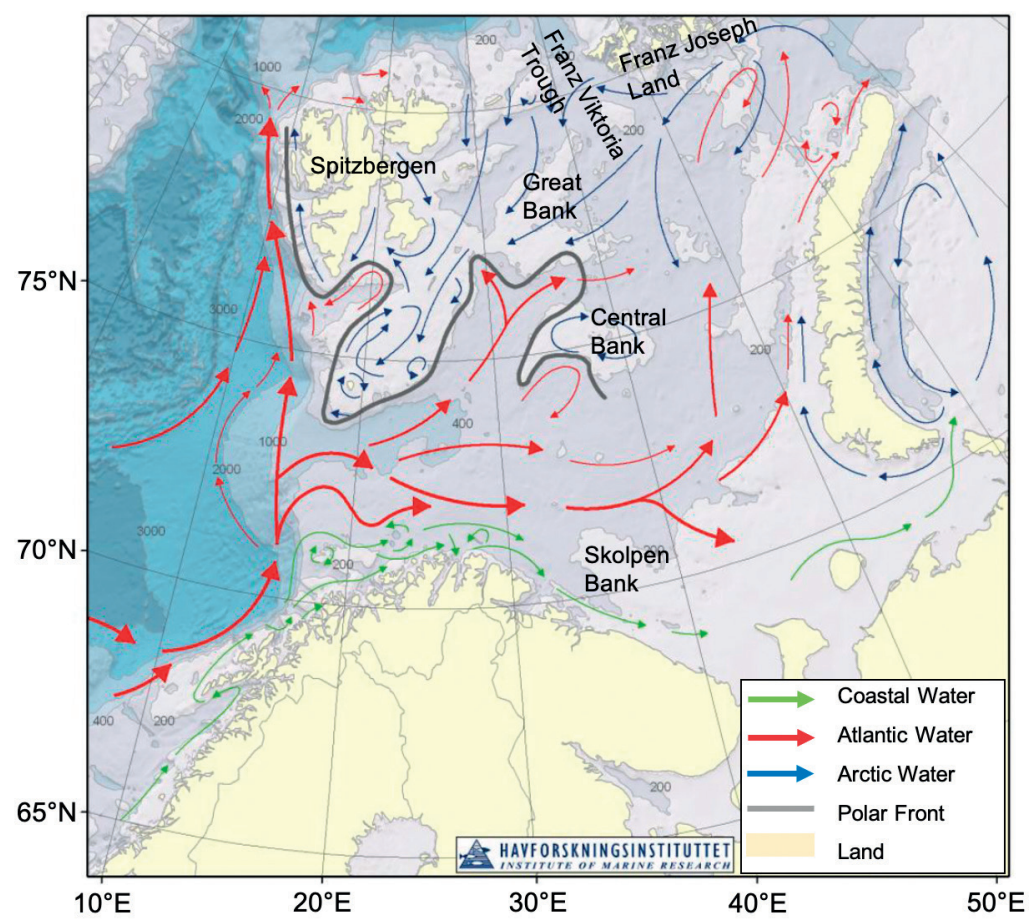

Fig. 2. Main features of circulation in the Barents Sea (modified after [18])

Рис. 2. Основные особенности циркуляции в Баренцевом море (на основе [18])

\section{METHODS}

To investigate horizontal and vertical distribution of SPM in the Barents Sea, 179 oceanographic stations were carried out during the expedition "Transarktika" leg 1 [19] aboard the RV "Akademik Tryoshnikov" between March and May 2019 (Fig. 1). 152 water samples of $1-2 \mathrm{~L}$ each, were collected from different water depths at 32 stations. While the ship was anchored to an ice floe (late March - beginning of May), a $2 \mathrm{~m}$ x $2 \mathrm{~m}$ hole at the side of the ship provided safe and reliable measurements with the shipboard CTD / Rosette. The water samples were filtered through pre-weighed MILLIPORE filters, with a diameter of $47 \mathrm{~mm}$ and a pore size of $0.45 \mu \mathrm{m}$, and subsequently dried at $50{ }^{\circ} \mathrm{C}$ onboard the ship. In the last processing step, the dried filters were weighed at GEOMAR in Kiel, Germany, to obtain SPM concentrations, taking into account the mean elutable portion of $0.2 \mathrm{mg} / \mathrm{L}$ of each filter. In order to obtain high resolution vertical profiles of SPM concentrations, a Seapoint Turbidity Meter was connected to a Seabird SBE 19 CTD at 159 stations. The turbidity meter emits light of $880 \mathrm{~nm}$ wavelength with a sampling frequency of $10 \mathrm{~Hz}$. It detects light scattered by suspended particles in water and generates an output voltage proportional to the suspended particles. The detector receives light scattered at angles between 15 and 150 degrees and has an accuracy of $\pm 2 \%$ [20]. The output is given in Nephelometric Turbidity Unit (NTU), a calibration unit based on formazine as a reference suspension. All SPM measurements obtained by filtration and weighing were correlated with corresponding turbidity meter measurements to obtain SPMturb mass 


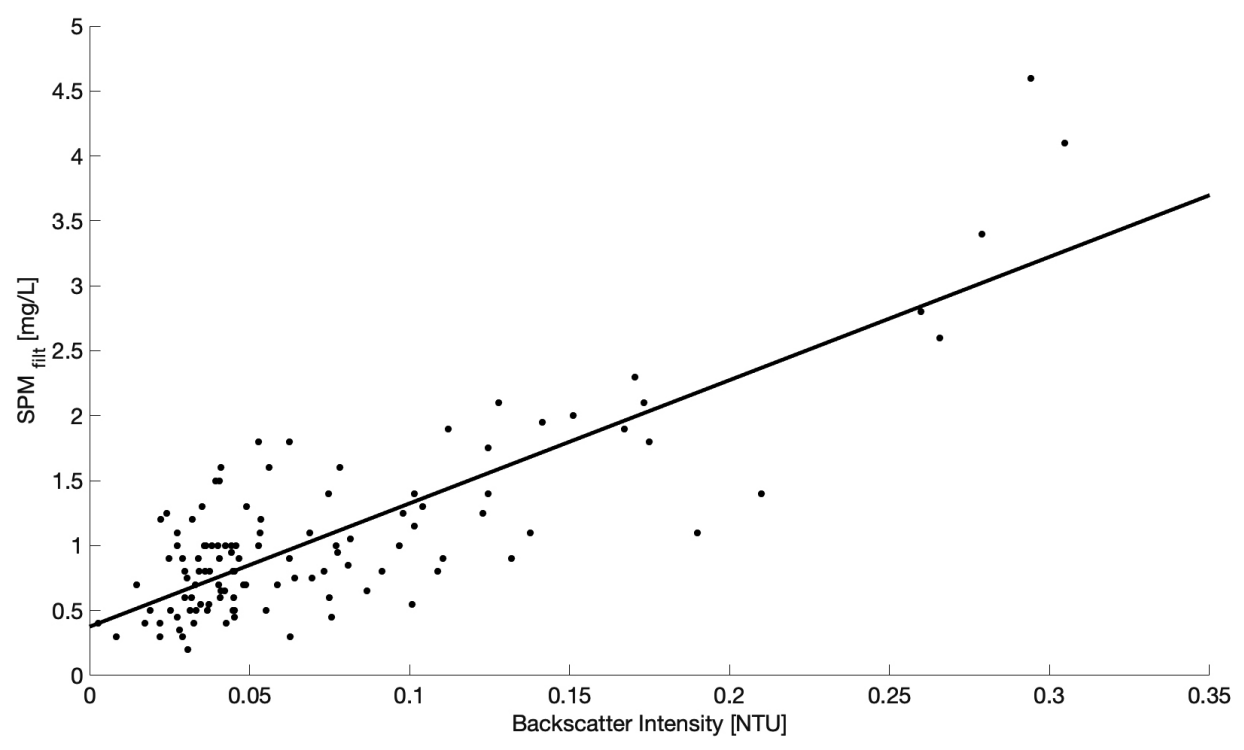

Fig. 3. Linear relationship between SPMfilt concentration $[\mathrm{mg} / \mathrm{L}]$ and optical backscatter intensity [NTU] $\left(r=0.82, \sigma_{e s t}=0.41\right)$.

A total of 115 SPM measurements were used

Рис. 3. Линейная зависимость между концентрацией взвешенного вещества SPMfilt [мг/л] и интенсивностью оптического обратного рассеяния [NTU] $\left(r=0,82, \sigma_{e s t}=0,41\right)$.

Всего было использовано 115 проб взвешенного вещества

concentrations, thereby taking into account the effects of different mineralogy, varying particle size and darkness on the response of the turbidity meter [21].

A good correlation was obtained between the weighed SPM concentrations and optical measurements (Fig. 3). The standard error of the estimate $\left(\sigma_{e s t}\right)$ is 0.41 . The linear relationship between SPMfilt and optical backscatter intensity can be expressed as: $S P M t u r b=9.49 \cdot B I+0.376$. Yet, the reflected variability between optical and weighed data shows the strong influence of different sediment compositions. In particular, the clay mineral distribution in surface sediments within the FVT region is highly variable, depending on whether the source area is located around Spitzbergen (Svalbard) or Franz Joseph Land [22].

\section{RESULTS}

\section{Vertical Distribution of SPM}

Turbidity and SPM measurements during ice-free conditions in the central Barents Sea reveal two distinct zones of SPM concentrations within the water column (Fig. 4 A1 $\mathrm{C} 1$ ). The upper zone, ranging from the surface to $150 \mathrm{~m}$, is characterized by a moderate increase in SPMturb concentrations with water depth and a range of concentrations between $0.4-1.0 \mathrm{mg} / \mathrm{L}$. A sharp increase in SPMturb as well as in SPMfilt concentrations below $150 \mathrm{~m}$ defines the lower zone, indicating the presence of a pronounced bottom nepheloid layer (BNL). Defining the upper boundary at concentrations of $1.5 \mathrm{mg} / \mathrm{L}$ the thickness of the BNL is approximately $40 \mathrm{~m}$. Within this layer, SPM concentrations range between $1.5 \mathrm{mg} / \mathrm{L}$ to $4 \mathrm{mg} / \mathrm{L}$ reaching maximum values near the seafloor. Only minor differences 

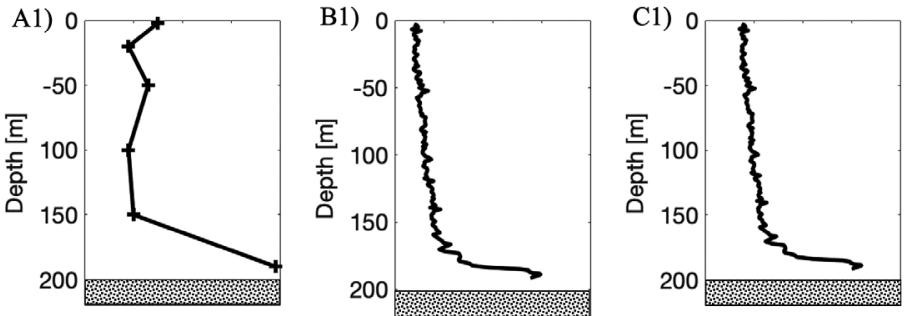

Franz Viktoria Trough
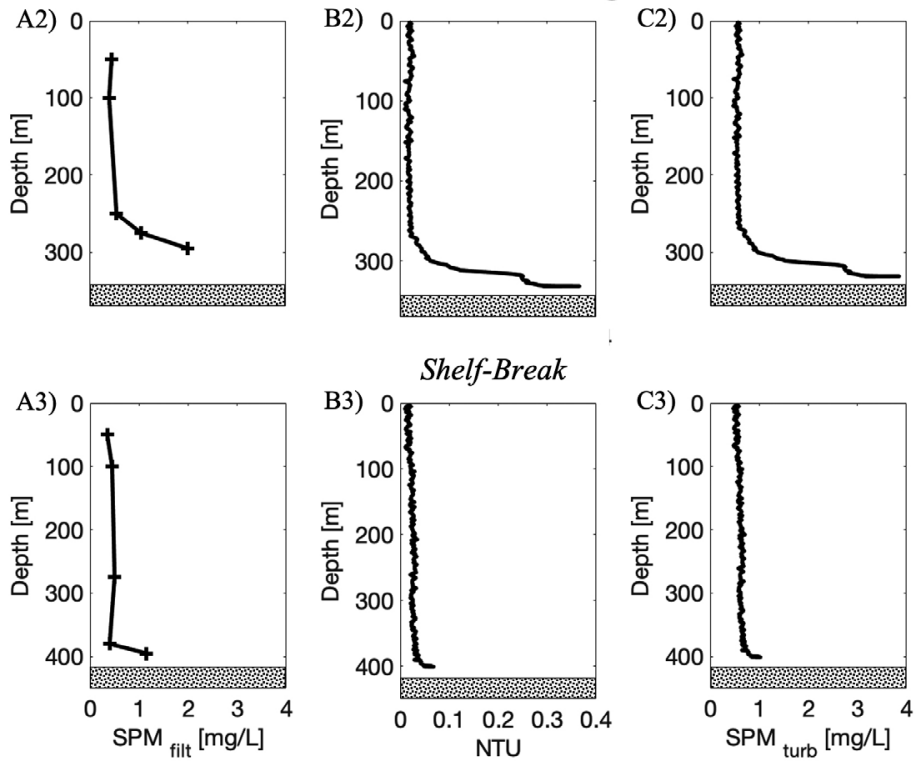

Fig. 4. Vertical distribution of SPMfilt (A1 - A3), backscatter intensity and (B1 - B3) and SPMturb $(\mathrm{C} 1-\mathrm{C} 3)$ in the central Barents Sea (left column), in the Franz Viktoria Trough (FVT station) (central column) and at the Shelf-Break (right column). The dotted area represents the seafloor.

Рис. 4. Вертикальное распределение взвешенного вещества SPMfilt (A1 - A3), интенсивности обратного рассеяния и $(\mathrm{B} 1-\mathrm{B} 3)$ и взвешенного вещества SPMturb $(\mathrm{C} 1-\mathrm{C} 3)$ в центральной части Баренцева моря (слева), в желобе Франц-Виктория (станция FVT) (в центре) и на континентальном склоне (справа). Пунктирная область представляет собой морское дно.

of $0.5 \mathrm{mg} / \mathrm{L}$ are observed between SPMfilt and SPMturb concentrations (Fig. 4A1, C1). The slight increase of SPMfilt concentrations at a water depth of $50 \mathrm{~m}$ (Fig. 4A1) are not clearly resolved in the backscatter data, showing no significant changes in concentrations.

A similar vertical SPM distribution compared to the central Barents Sea is observed in the southern Franz Viktoria Trough under ice-covered conditions (Fig. 5A2 - C2). However, the range of SPMturb and SPMfilt concentration is noticeably lower in the upper water column, only varying between $0.4-0.6 \mathrm{mg} / \mathrm{L}$. The BNL is comparably thinner with a thickness of approximately $30 \mathrm{~m}$ but with slightly higher SPMturb concentrations of up to $4.0 \mathrm{mg} / \mathrm{L}$ close to the seafloor. The upper boundary appears to be more pronounced than in the central Barents Sea. This sharp transition zone may further explain the observed differences of SPMfilt and SPMturb concentrations at $300 \mathrm{~m}$ water depth (Fig. 4A2, C2). 
In contrast to the central Barents Sea and the southern FVT, turbidity and SPMturb concentrations close to the shelf break are significantly reduced in the entire water column, ranging between $0.4-1 \mathrm{mg} / \mathrm{L}$ (Fig. 4A3 - C3). A well-defined BNL is absent, although concentrations slightly increase at depths closer to the seafloor.

\section{Horizontal distribution of SPM}

A south - north transect from the northern tip of Kola Peninsula to the shelf break between Spitzbergen (Svalbard) and Franz Joseph Land along $39^{\circ} \mathrm{E}$ is studied (Fig. 5) to investigate the horizontal distribution of SPM. The BNL in the southern and central Barents Sea is distinct, noticeably varying in thickness and clearly influenced by ocean bathymetry. Highest SPMturb concentrations are observed at the northern flank of Skolpen Bank and along the Central Bank. Furthermore, elevated SPMturb concentrations are observed in valleys along the Central Bank and Great Bank. Towards the north, the bottom nepheloid layer decreases in thickness and in concentration. North of the ice-edge at $78^{\circ} \mathrm{N}$, the entire water column becomes less turbid and the BNL decreases in its intensity and becomes almost absent at the shelf break.

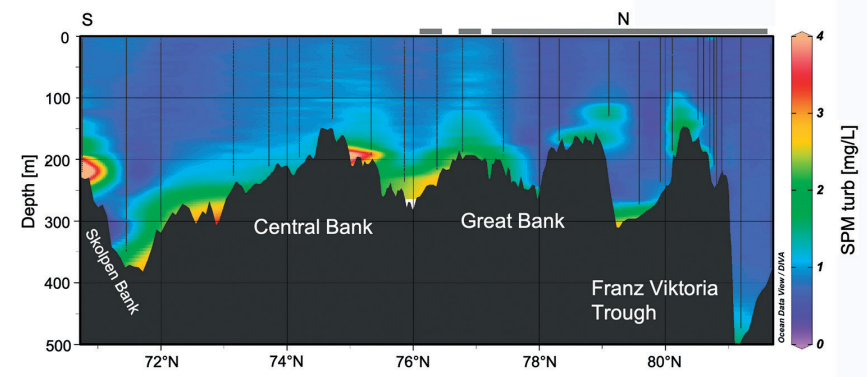

Fig. 5. SPMturb concentrations along a $\mathrm{S}-\mathrm{N}$ transect at $39^{\circ} \mathrm{E}$. The grey dashed line represents a rough estimation of sea-ice concentration along the transect (solid line corresponds to $100 \%$ ice cover, no line corresponds to $0 \%$ ice cover). Bathymetry from IBCAO V3.0 [17]

Рис. 5. Концентрации взвешенного вещества SPMturb вдоль разреза $\mathrm{S}-\mathrm{N}$ на $39^{\circ}$ в.д. Серая пунктирная линия представляет собой грубую оценку сплоченности морского льда вдоль разреза (сплошная линия соответствует концентрации $100 \%$, отсутствие линии соответствует концентрации 0 \%). Батиметрия IBCAO V3.0 [17]

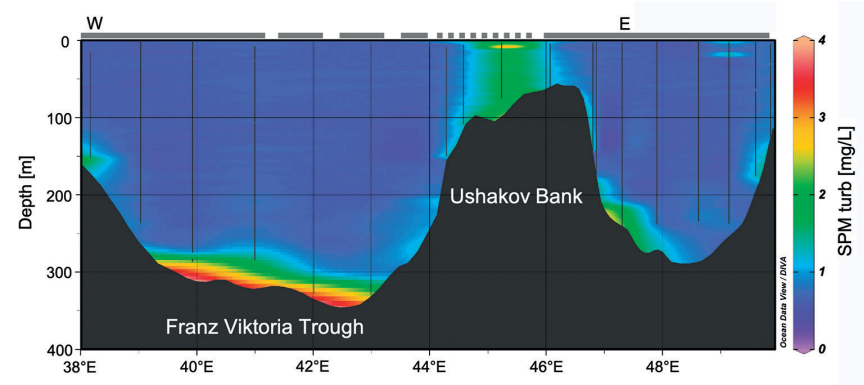

Fig. 6. SPMturb concentrations along a W-E transect between $79^{\circ} \mathrm{N}$ and $80^{\circ} \mathrm{N}$. The grey dashed line represents a rough estimation of sea-ice concentration along the transect. Bathymetry from IBCAO V3.0 [17].

Рис. 6. Концентрации взвешенного вещества SPMturb вдоль разреза W - Е между $79^{\circ}$ с.ш. и $80^{\circ}$ с.ш. Серая пунктирная линия представляет собой грубую оценку сплоченности морского льда вдоль разреза. Батиметрия IBCAO V3.0 [17]). 
A west - east transect across Franz Viktoria Trough (FVT) towards Franz Joseph Land reveals a distinct BNL in the deepest parts of the trough between $40^{\circ} \mathrm{E}$ and $42^{\circ} \mathrm{E}$ with a sharp upper boundary and maximum SPMturb concentrations of up to $4 \mathrm{mg} / \mathrm{L}$ (Fig. 6). Yet, east of Ushakov Bank, SPMturb concentrations are noticeably lower, varying between $0.25 \mathrm{mg} / \mathrm{L}$ and $2 \mathrm{mg} / \mathrm{L}$, and a BNL is absent. Across Ushakov Bank at $45^{\circ} \mathrm{E}$ high SPMturb concentrations are observed throughout the entire water column. During the sampling at this station a large polynya was observed east of Franz Joseph Land which also covered the area around Ushakov Bank (Fig. 1). This recurring polynya is a common feature during the winter and is referred to the Franz Joseph Land Polynya [23].

\section{DISCUSSION}

The vertical and horizontal distribution of SPM showed a pronounced BNL in icefree and under ice-covered conditions. A general decrease in thickness of the BNL as well as in SPM concentrations was observed from south to north. The formation of a BNL is generally related to local resuspension of particles by waves, currents and internal waves [24, 25]. In terms of the Barents Sea, inflowing Atlantic Water masses from the Norwegian Sea, spreading eastwards across the shelf, and cold Arctic Water, play a key role in the oceanographic setting (Fig. 2). Due to the absence of sea ice, strong winter storms can lead to intensified surface and bottom currents in the southern Barents Sea $[26,27]$. Therefore, high SPM concentrations observed along the flanks of Skolpen Bank and across the Central Bank were possibly caused by strong eastward flows of modified Atlantic Water. Compared to SPM data obtained in September 2016 by [8], near bottom SPM concentrations from this study obtained during winter are notably higher. This may also be attributed to the general higher intensity of storms during winter [26] causing stronger currents and hence higher resuspension in the central Barents Sea. Further north, the Barents Sea is seasonally ice covered which generally leads to reduced current speeds. Hence, less resuspension could explain the lower SPM concentrations observed in the northern region. However, local increases in SPM as observed on Ushakov Bank might be explained by wind-induced resuspension in a polynya (Fig. 6) or very intense vertical convection over the bank [16]. Although it remains unclear, due to a lack of current data, whether the particulate matter was locally resuspended or advected laterally from shallower regions further north.

Connecting the Barents Sea shelf and the deep Arctic Ocean, the FVT could be a key pathway for exporting shelf-derived material. According to [28] and [29] Atlanticderived waters enter the Barents Sea through the western part of FVT, while Cold Bottom Waters and southern Barents Sea Atlantic-derived waters are exiting towards the north in the eastern part of the FVT. Therefore, the absence of the BNL at the slope can be explained by the station's positions being located mostly in the western FVT where less turbid water masses from the Arctic Ocean dominate. Assuming a near-bottom northward flow in the eastern FVT and relating it to the well pronounced BNL in the southern FVT, leads to the conclusion that shelf material can be exported through the FVT within the BNL during winter. Due to the absence of a BNL in the FVT in late summer / early autumn [8] it can further by implied that most of the bottom sediment transport occurs during wintertime. Yet, to further support this hypothesis, year-round current and SPM measurements are needed. 


\section{CONCLUSION}

Sedimentological investigations were conducted in the Barents Sea to gain new insights into the distribution of suspended particulate matter during late winter. A distinct bottom nepheloid layer was observed during the sampling period across the entire Barents Sea shelf with a decreasing intensity trend from the south towards the north. The highest SPM concentrations of up to $4 \mathrm{mg} / \mathrm{L}$ were observed in bathymetric troughs (e.g. Franz Viktoria Trough) and at the flanks of bathymetric elevations (e.g. Skolpen Bank).

Relating this study to SPM investigations carried out mainly in autumn which observed only very low SPM concentrations below $1 \mathrm{mg} / \mathrm{L}$ leads to the conclusion that a distinct BNL is formed in late autumn or winter. Hence, sediment transport on the Barents Sea shelf may be most pronounced during winter. The Franz Viktoria Trough, a deep valley with water depths of more than $400 \mathrm{~m}$ could act as an important transport conduit for shelf material into the Eurasian Basin. In order to quantify sediment transport within the BNL and to gain more certainties about the fate of the suspended material in this region, more detailed investigations of SPM combined with current measurements at the continental slope are needed.

Competing interests. The authors declare that they have no competing interests.

Funding. This research was supported by the Russian-German research projects: "CATS: The Changing Arctic Transpolar System" funded by the BMBF (03F0776) and by the Russian Foundation for Basic Research (RFBR) grant 18-05-60083.

Acknowledgements. The authors would like to thank Roshydromet for financing the expedition "Transarktika-2019". We are deeply grateful to the captain of the R/V "Akademik Tryoshnikov" D.A. Karpenko and the ship crew for comprehensive assistance in providing scientific research during the expedition. We would also like to thank the Technology \& Logistics Centre of GEOMAR, the Otto-Schmidt-Laboratory for Polar and Marine Research at the AARI and the Custom Department of AARI. We would also like to thank two anonymous reviewers for the very helpful comments and suggestions.

\section{REFERENCES}

1. Sorteberg A., Kvingedal B. Atmospheric forcing on the Barents sea winter ice extent. Journal of Climate. 2006, 19 (19): 4772 - 4784. https://doi.org/10.1175/JCLI3885.1.

2. Serreze M.C., Meier W.N. The Arctic's sea ice cover: Trends, variability, predictability, and comparisons to the Antarctic. Annals of the New York Academy of Sciences. 2019，1436(1): $36-$ 53. https://doi.org/10.1111/nyas.13856.

3. Eicken H., Gradinger R., Gaylord A., Mahoney A., Rigor I., Melling H. Sediment transport by sea ice in the Chukchi and Beaufort Seas: Increasing importance due to changing ice conditions? Deep Sea Research Part II: Topical Studies in Oceanography. 2005, 52 (24): 3281- 3302. https://doi. org/10.1016/j.dsr2.2005.10.006.

4. Carmack E., Barber D., Christensen J., Macdonald R., Rudels B., Sakshaug E. Climate variability and physical forcing of the food webs and the carbon budget on panarctic shelves. Progress in Oceanography. 2006, 71 (2): 145 — 181. https://doi.org/10.1016/j.pocean.2006.10.005.

5. Marsh A.G., Tenore K.R. The role of nutrition in regulating the population dynamics of opportunistic, surface deposit feeders in a mesohaline community. Limnology and Oceanography. 1990, 35 (3): 710-724. https://doi.org/10.4319/1o.1990.35.3.0710.

6. Graf G., Rosenberg R. Bioresuspension and biodeposition: A review. Journal of Marine Systems. 1997, 11 (3): 269-278. https://doi.org/10.1016/S0924-7963(96)00126-1. 
7. Retamal L., Bonilla S., Vincent W.F. Optical gradients and phytoplankton production in the Mackenzie River and the coastal Beaufort Sea. Polar Biology. 2007, 31 (3): 363 - 379. https://doi. org/10.1007/s00300-007-0365-0

8. Politova N.V., Kravchishina M.D., Novigatsky A.N., Lokhov A.S. Dispersed sedimentary matter of the Barents Sea. Oceanology. 2019, 59 (5): 697 - 714. https://doi.org/10.1134/S0001437019050151.

9. Lisitzin A.P. Sedimentary system of the Arctic Ocean - interactions between outer and inner geospheres. A. P. Lisitzin (Hrsg.), Sea-Ice and Iceberg Sedimentation in the Ocean: Recent and Past. Springer. 2002: 203 - 226. https://doi.org/10.1007/978-3-642-55905-1_8

10. Lisitzin A.P., Shevchenko V.P., Burenkov V.I. Hydrooptics and suspended matter of Arctic seas. Atmosph. Ocean Optic. 2000, 13 (1): $61-71$.

11. Wegner C., Hölemann J.A., Dmitrenko I., Kirillov S., Tuschling K., Abramova E., Kassens H. Suspended particulate matter on the Laptev Sea shelf (Siberian Arctic) during ice-free conditions. Estuarine, Coastal and Shelf Science. 2003, 57 (1): 55 - 64. https://doi.org/10.1016/S02727714(02)00328-1.

12. Wegner C., Bauch D., Hölemann J. A., Janout M. A., Heim B., Novikhin A., Kassens H., Timokhov L. Interannual variability of surface and bottom sediment transport on the Laptev Sea shelf during summer. Biogeosciences. 2013, 10 (2): 1117 - 1129. https://doi.org/10.5194/bg-10-1117-2013.

13. Rutgers van der Loeff M. M., Meyer R., Rudels B., Rachor E. Resuspension and particle transport in the benthic nepheloid layer in and near Fram Strait in relation to faunal abundances and 234Th depletion. Deep Sea Research Part I: Oceanographic Research Papers. 2002, 49 (11): 1941 — 1958. https://doi.org/10.1016/S0967-0637(02)0113-9.

14. Schäfer P., Ritzrau W.A., Schlüter M., Thiede J. (Eds.). The Northern North Atlantic: a changing environment. Springer, Berlin, 2001: $491 \mathrm{p}$.

15. Peinert R., Antia A., Bauerfeind E., V. Bodungen B., Haupt O., Krumbholz M., Peeken I., Ramseier R.O., Voss M., Zeitzschel B. Particle flux variability in the Polar and Atlantic biogeochemical provinces of the Nordic Seas. Schäfer, P., Ritzrau, W., Schlüter, M., Thiede, J. (Eds.), The Northern North Atlantic: a changing environment. Springer, Berlin, 2001: 53 - 68.

16. Frolov I.E., Ivanov V.V., Filchuk K.V., Makshtas A.P., Kustov V.Yu., Mahotina I.A., Ivanov B.V., Urazgildeeva A.V., Syoemin V.L., Zimina O.L., Krylov A.A., Bogin V.A., Zakharov V.Yu., Malyshev S.A., Gusev E.A., Baryshev P.E., Pilgaev S.V., Kovalev S.M., Turyakov A.B. Transarktika-2019: winter expedition in the Arctic Ocean on the R/V "Akademik Tryoshnikov". Problemy Arktiki i Antarcktiki. Arctic and Antarctic Research. 2019, 65 (3): 255 - 274. https://doi.org/10.30758/0555-2648-201965-3-255-274.

17. Jakobsson M., Mayer L., Coakley B., Dowdeswell J. A., Forbes S., Fridman B., Hodnesdal H., Noormets R., Pedersen R., Rebesco M., Schenke H. W., Zarayskaya Y., Accettella D., Armstrong A., Anderson R. M., Bienhoff P., Camerlenghi A., Church I., Edwards M., et al. The International Bathymetric Chart of the Arctic Ocean (IBCAO) Version 3.0. Geophysical Research Letters. 2012, 39 (12): L12609. https://doi.org/10.1029/2012GL052219.

18. Stiansen J.E., Korneev O., Titov O., Arneberg P. (Eds.), Filin A., Hansen J. R., Høines A., Marasaev $S$. (Co-eds.) Joint Norwegian-Russian environmental status 2008. Report on the Barents Sea Ecosystem. Part II — Complete report. IMR/PINRO Joint Report Series. 2009, 3: 375 p.

19. Frolov I.E., Ivanov V.V. Nauchno-technicheskiy otchet (predvaritel'niy) o resul'tatakh komplexsnykh nauchnykh issledovaniy dexpeditsii na NES "Akafemik Tryoshnikov" d Barentsevom more i prilegauschey chasti Arkticheskogo basseina ("Transarktika-2019", perviy etap), 12 reis NES "Akademik Tryoshnikov". Mart-May 2019 g. Scientific-technical report (Preliminary) on the results of multidisciplinary scientific investigations during an expedition onboard RV "Akademik Tryoshnikov" to the Barents Sea and the adjacent Arctic basin ("Transarktika-2019", Leg 1), 12th Expedition of RV "Akademik Tryoshnikov". March — May 2019. St. Petersburg: AARI funds, O-4098, 2019: 419 p. [In Russian]. 
20. Seapoint Sensors Inc. Seapoint Turbidity Meter: User Manual. 2013. Available at: URL: http:// www.seapoint.com/pdf/stm_um.pdf (accessed 3.09.2020).

21. Maa J. P.-Y., Xu J., Victor M. Notes on the performance of an optical backscatter sensor for cohesive sediments. Marine Geology. 1992, 104 (1): 215 - 218. https://doi.org/10.1016/0025-3227(92)90096-Z.

22. Wahsner M., Müller C., Stein R., Ivanov G., Levitan M., Shelekhova E., Tarasov G. Clay-mineral distribution in surface sediments of the Eurasian Arctic Ocean and continental margin as indicator for source areas and transport pathways — a synthesis. Boreas. 1999, 28 (1): 215 - 233. https://doi. org/10.1111/j.1502-3885.1999.tb00216.x.

23. Barber D.G., Massom R.A. The role of sea ice in Arctic and Antarctic polynyas. In W. O. Smith \& D.G. Barber (Hrsg.). Elsevier Oceanography Series, Elsevier. 2007, 74: 1—54. https://doi.org/10.1016/ S0422-9894(06)74001-6.

24. Cacchione D.A., Drake D.E. Nepheloid layers and internal waves over continental shelves and slopes. Geo-Marine Letters. 1986, 6: 147 - 152.

25. Gardner W.D. Periodic resuspension in Baltimore canyon by focusing of internal waves. Journal of Geophysical Research. 1989, 94 (C12): 18185 - 18194. https://doi.org/10.1029/JC094iC12p18185.

26. Ingvaldsen R., Loeng H., Asplin L. Variability in the Atlantic inflow to the Barents Sea based on a one-year time series from moored current meters. Continental Shelf Research. 2002, 22 (3): 505 519. https://doi.org/10.1016/S0278-4343(01)00070-X.

27. Sternberg R.W., Aagaard K., Cacchione D., Wheatcroft R.A., Beach R.A., Roach A.T., Marsden M.A.H. Long-term near-bed observations of velocity and hydrographic properties in the northwest Barents Sea with implications for sediment transport. Continental Shelf Research. 2001, 21 (5): 509 - 529. https://doi.org/10.1016/S0278-4343(00)00103-5.

28. Rudels B. On the mass balance of the Polar Ocean, with special emphasis on the Fram Strait. Norsk Polarinstitutt. 1987: 53 p.

29. Pfirman S.L., Bauch D., Gammelsrød T. The Northern Barents Sea: water mass distribution and modification. The Polar oceans and their role in shaping the global environment. American Geophysical Union (AGU). 1994: 77 — 94. https://doi.org/10.1029/GM085p0077.

\section{Распределение взвешенных частиц в Баренцевом море в конце зимы 2019 г. (расширенный реферат)}

В условиях изменения климата происходит сокращение площади ледяного покрова как летом, так и зимой, что влечет изменения в гидрофизических и биогеохимических циклах на сезонно-безледных шельфах Евразийского бассейна. В свою очередь увеличение продолжительности периода открытой воды приводит к интенсификации образования взвешенного осадка и береговой эрозии в связи с увеличением ветровой нагрузки и высоты волн. Это влияет на оптические свойства водной толщи и, следовательно, на биологическую продуктивность в этом регионе. Исследования в восточной части Баренцева моря в летнее время показывают высокие концентрации взвешенного вещества (ВВ) в придонном слое, однако в осеннее время в районе желоба Франц-Виктория наблюдаются низкие концентрации в этом слое. Наличие подобных донных нефелоидных слоев (ДНС) имеет важнейшее значение для бентических организмов, поскольку от этого зависит их кормовая база. Кроме того, большая часть переноса поперек-склоновых осадков, а также вынос органического углерода с шельфа происходит в пределах ДНС. Для изучения вертикального и горизонтального распределения концентрации ВВ в Баренцевом море в рамках первого этапа экспедиции «Трансарктика-2019» на НЭС «Академик Трёшников» в марте — мае 2019 г. на 32 океанографических станциях было отобрано 152 1-2-литровых пробы воды с последующей фильтрацией и взвешиванием фильтров. Также на 159 станциях были получены вертикальные профили распределения оптического обратного рассеяния с помощью оптического датчика мутности. С использованием 115 проб была определена линейная зависимость концентрации ВВ от величины оптического обратного рассеяния, позволившая восстановить профили концентрации ВВ по данным датчика мутности. 
Анализ результатов позволил получить следующую картину вертикального распределения концентрации ВВ в разных областях моря. В центральной части хорошо прослеживаются два слоя: от поверхности до 150 метров с диапазоном концентраций 0,4 - 1 мг/л и придонный 40-метровый нефелоидный с диапазоном концентраций от 1,5 до 4 мг/л непосредственно у дна. В южной части желоба Франц-Виктория наблюдается похожая картина, но с меньшими концентрациями: 0,4-0,6 мг/л в верхнем слое и чуть большими (до 4 мг/л) в нефелоидном 30-метровом слое. В северной же части желоба Франц-Виктория, ближе к континентальному склону, выраженный ДНС отсутствует, концентрация ВВ по всей толще варьируется в пределах 0,4-1 мг/л. Горизонтальное распределение вдоль 39-го меридиана показывает повышенные концентрации ВВ у банок центральная и Сколпен, в целом к северу наблюдается понижение концентрации и уменьшение ДНС. В желобе Франц-Виктория по данным поперечного разреза определяются повышенные концентрации ВВ на западном и пониженные на восточном склоне. На распределение концентрации ВВ в Баренцевом море влияет большое количество факторов. Среди наиболее значимых: наличие ледяного покрова - открытая вода способствует развитию волнения, а также вертикальной конвекции и, тем самым, повторному распространению взвеси, трансформированная атлантическая вода также может быть причиной повышенных концентраций ВВ. Распределение концентрации ВВ в желобе Франц-Виктория может быть объяснено затоком вод атлантического происхождения с низкими концентрациями ВВ вдоль западного берега с севера и выходом холодных придонных и южных баренцевоморских вод с повышенными концентрациями вдоль восточного склона с юга. Отсутствие ДНС в конце лета / начале осени и наличие его зимой позволяет предположить, что большая часть транспорта ВВ происходит в зимнее время, однако эта гипотеза требует подтверждения на основании круглогодичных данных о концентрации ВВ и течений. 